\title{
Synthesis of Orthogonally Protected Thioamide Dipeptides for Use in Solid-Phase Peptide Synthesis
}

\author{
Fintan Kelleher \\ Technological University Dublin, fintan.kelleher@tudublin.ie \\ Kim Manzor \\ Institute of Technology Tallaght
}

Follow this and additional works at: https://arrow.tudublin.ie/ittsciart

Part of the Medicinal-Pharmaceutical Chemistry Commons, and the Organic Chemistry Commons

\section{Recommended Citation}

Kelleher, F. \& Manzor, K. (2016) Synthesis of Orthogonally Protected Thioamide Dipeptides for Use in Solid-Phase Peptide Synthesis, Tetrahedron Letters Vol. 57, Issue 47,pp.5237-5239. DOI: 10.1016/ j.tetlet.2016.10.036

This Article is brought to you for free and open access by the School of Science and Computing at ARROW@TU Dublin. It has been accepted for inclusion in Articles by an authorized administrator of ARROW@TU Dublin. For more information, please contact arrow.admin@tudublin.ie, aisling.coyne@tudublin.ie, gerard.connolly@tudublin.ie. Funder: Science Foundation Ireland 
Synthesis of orthogonally protected thioamide dipeptides for use in solid-phase peptide synthesis

\author{
Kim Manzor and Fintan Kelleher*
}

Molecular Design \& Synthesis Group, Centre of Applied Science for Health, Institute of Technology Tallaght, Dublin 24, Ireland

Corresponding Author: Dr. Fintan Kelleher

Address:

Department of Science,

Institute of Technology Tallaght,

Tallaght,

Dublin 24,

Ireland.

Phone Number:

(+353 1) 4042869

e-mail address:

fintan.kelleher@ittdublin.ie 


\section{Graphical abstract:}

Synthesis of orthogonally protected thioamide dipeptides for use in solid-phase peptide synthesis

Kim Manzor and Fintan Kelleher*

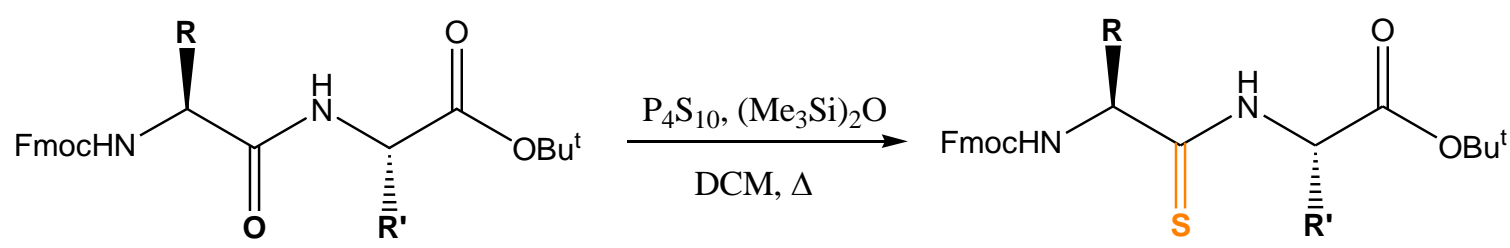




\title{
Synthesis of orthogonally protected thioamide-containing dipeptides for use in solid- phase peptide synthesis
}

\author{
Kim Manzor and Fintan Kelleher ${ }^{*}$
}

Molecular Design \& Synthesis Group, Centre of Applied Science for Health, Institute of Technology Tallaght, Dublin 24, Ireland

\begin{abstract}
Orthogonally protected thioamide-containing dipeptides were efficiently and cleanly prepared from the precursor dipeptides using Curphey's method $\left(\mathrm{P}_{4} \mathrm{~S}_{10}\right.$, hexamethyldisiloxane (HMDO), reflux, DCM) in 67-96\% isolated yield. This was in contrast to the use of Lawesson's or Berzelius' reagents where significant issues with reaction noncompletion, decomposition and purification were observed. Subsequent clean removal of the dipeptides' $t$-butyl ester protecting groups gave thioamide dipeptide acids which were suitable for use in solid-phase peptide synthesis (SPPS).
\end{abstract}

Keywords: thioamide; thionation; Curphey's method; thiopeptides.

The WHO has recognised antimicrobial resistance (AMR) as one of the greatest challenges facing humankind, with some bacterial species already becoming resistant to all currently used antibiotics. ${ }^{1}$ A recent report has predicted that, if the situation is left unchecked, by 2050 up to 10 million people annually will die from bacterial infections, with an overall cost of US\$100 trillion. ${ }^{2}$ However, the pipeline of new antibiotics for tackling this crisis is very low since most of the world's major pharmaceutical companies no longer have antibiotic discovery programmes. In order to address this critical issue, there is an urgent global need for the development of a wide range of new antibiotic classes. The worldwide market for peptide-based therapeutics is forecasted to grow to $\$ 23.7$ billion by $2020,{ }^{3}$ where chemically synthesised peptides will be a significant, and growing, proportion of this figure. Peptide-based antimicrobials are a class that has significant potential in combatting AMR, and include lantibiotics and antimicrobial peptide (AMPs). ${ }^{4} \mathrm{~A}$ further class is the thiopeptide antibiotics, which include thiostrepton, siomycins and thiopeptins, 
amongst many others. ${ }^{5}$ The chemical synthesis of many thiopeptides requires the efficient preparation of thioamides, in place of amides, as the peptide link. These thioamides can then be left with the thioamide peptide bond intact as bioisosteres, or further converted to the thiazoline and thiazole heterocyclic moieties, which are common in thiopeptide antibiotics. Peptides containing thioamides are known in some cases to improve aqueous solubility and pharmacokinetic properties, such as half-life. ${ }^{6}$ The synthesis of thioamides has been reviewed, and one of the principal methods used is the thionation of amides. ${ }^{7} \mathrm{~A}$ large number of methods have been developed for the thionation of carbonyl groups to their thiocarbonyl analogues, where the main reagents include Lawesson's reagent, ${ }^{8}$ Berzelius' reagent ${ }^{9}$, more recently Curphey's method. ${ }^{10}$ The use of a $\mathrm{P}_{4} \mathrm{~S}_{10}$-pyridine complex was also reported by Bergman and co-workers in 2011. ${ }^{11}$

As part of a project for preparing antimicrobial peptides containing specific thioamide isosteres in place of amides by solid-phase peptide synthesis (SPPS), there was a need for the efficient synthesis of specific peptidic thioamide moieties. It is known that it is not possible to conduct the thionation reaction of an amide bond when the peptide is already on a solid-phase resin. It is also not possible to selectively thionate a particular amide in an oligopeptide or polypeptide sequence. Therefore, we required the solution-phase synthesis of orthogonally protected dipeptide fragments containing the thioamide peptide bond, where the fragment could then be incorporated into a peptide sequence using SPPS. Our initial targets required the preparation of dipeptides of type A) Fmoc-NH-Ile-Xaa-COOBu ${ }^{t}$, where Xaa was glycine, alanine, phenylalanine, and type B) Fmoc-NH-Xaa-Leu-COOBu ${ }^{t}$ where Xaa were similar residues to type A (Fig. 1). Fmoc SPPS was selected as the method of choice for preparation of the required peptides.

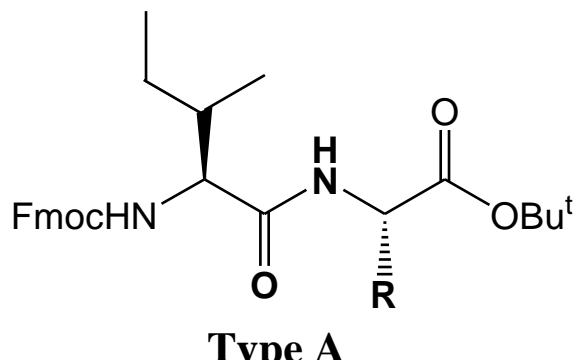

Type A<smiles>CCCCCCCCC(=O)OCC(C)C</smiles>

Type B

$$
\mathrm{R} \text { or } \mathrm{R}^{\prime}=\mathrm{H}, \mathrm{CH}_{3}, \mathrm{PhCH}_{2}
$$

Figure 1. Structures of the two types of dipeptide precursor targets 
A review of the literature showed that Strømgaard and co-workers ${ }^{12}$ recently reported the successful use of Lawesson's reagent in tetrahydrofuran at room temperature for the preparation of thioamide-containing dipeptides in good isolated yields of $>80 \%$. Before attempting the amide thionation reaction, the dipeptide precursors for the type $\mathbf{A}$ fragments were efficiently prepared in acetonitrile, in 93-97\% isolated yield, by the coupling of Fmoc-L-Ile-COOH with the required amino acid protected as its $t$-butyl ester, using HBTU in the presence of triethylamine (Scheme 1). ${ }^{12}$

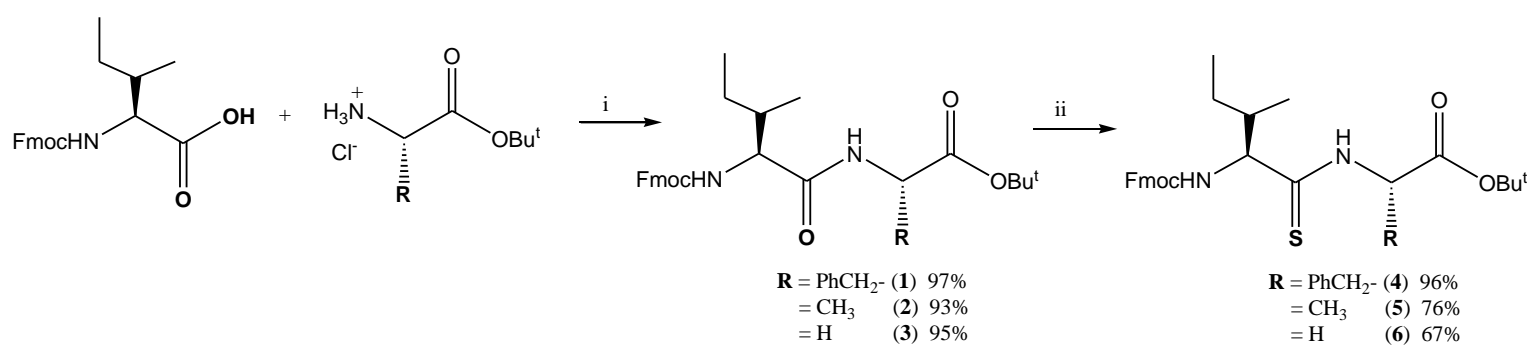

Scheme 1. Synthesis of Type A dipeptides and their thioamide analogues. Reagents and conditions; i) $\mathrm{Et}_{3} \mathrm{~N}, \mathrm{HBTU}, \mathrm{CH}_{3} \mathrm{CN}$, rt, 2h; ii) $\mathrm{P}_{4} \mathrm{~S}_{10},\left(\mathrm{Me}_{3} \mathrm{Si}\right)_{2} \mathrm{O}, \mathrm{DCM}$, reflux

The type B dipeptides were similarly prepared by the coupling of Fmoc protected L-amino acids with L-leucine $t$-butyl ester under similar reaction conditions. In this case the isolated yields were slightly lower (86-96\%).

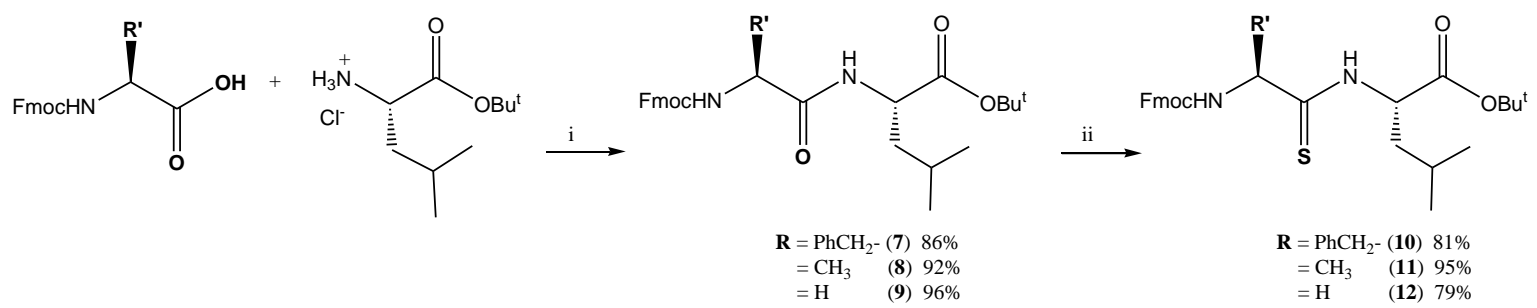

Scheme 2. Synthesis of Type $\mathbf{B}$ dipeptides and their thioamide analogues. Reagents and conditions; i) $\mathrm{Et}_{3} \mathrm{~N}, \mathrm{HBTU}, \mathrm{CH}_{3} \mathrm{CN}$, rt, 2h; ii) $\mathrm{P}_{4} \mathrm{~S}_{10},\left(\mathrm{Me}_{3} \mathrm{Si}\right)_{2} \mathrm{O}, \mathrm{DCM}$, reflux

With the dipeptides in hand, the next step involved selective thionation of the amide group to a thioamide in the presence of both carbamate and ester functional groups. Although Bergman and co-workers reported the use of the $\mathrm{P}_{4} \mathrm{~S}_{10}$-pyridine complex for amide thionation, the reaction conditions required reflux in acetonitrile (b.pt. $85{ }^{\circ} \mathrm{C}$ ), pyridine (b.pt. $115^{\circ} \mathrm{C}$ ) or in dimethyl sulfolane at 165-175 ${ }^{\circ} \mathrm{C}$. In our experience, heating of orthogonally protected dipeptides at temperatures of $80-90{ }^{\circ} \mathrm{C}$, leads to significant decomposition, so it was felt that Bergman's method was too harsh for the examined 
dipeptide substrates. Likewise Shibihara and Murai's method for converting amides to thioamides using elemental sulfur required reflux in toluene at $115^{\circ} \mathrm{C},{ }^{13}$ while Poupaert and co-workers reported the use of $\mathrm{P}_{4} \mathrm{~S}_{10}$ in the presence of $\mathrm{Al}_{2} \mathrm{O}_{3}$ in 1,4-dioxane at reflux (b.pt. $\left.101{ }^{\circ} \mathrm{C}\right) .{ }^{14}$ Both sets of conditions were also considered too harsh in our case.

As a result, Strømgaard's method for selective amide thionation in the presence of both carbamate and ester carbonyl groups was used. ${ }^{12}$ However, in our hands it was found that even after further multiple additions of molar equivalents of Lawesson's reagent, incomplete reaction was observed with significant quantities of the starting dipeptide still present in each case. It was also found when using this method, that purification of the required thioamide peptide was laborious due to difficulties in separating the required compounds from by-products formed from the Lawesson's reagent. Significant time and effort was expended trying to optimise this reaction by changing the solvent, temperature, reaction time, and the use of new batches of Lawesson's reagent, however, to no avail. A significant amount of the starting dipeptide was present, in each case, as well decomposition products were observed.

Moving on, Berzelius' reagent $\left(\mathrm{P}_{4} \mathrm{~S}_{10}\right)$ was used, but as for Lawesson's reagent after many attempts, using a variety of reaction conditions, incomplete reaction and/or decomposition was always observed. As for the use of Lawesson's reagent, significant difficulties with purification also arose.

Finally Curphey's method, ${ }^{10}$ using $\mathrm{P}_{4} \mathrm{~S}_{10}$ (1.1 molar equiv.) in the presence of hexamethyldisiloxane (HMDO, 5.5 molar equiv.) was attempted. After some optimisation it was found that the use of dichloromethane as solvent at reflux, as well as the further addition of the same amount of $\mathrm{P}_{4} \mathrm{~S}_{10}$ and $\mathrm{HMDO}$ after $5 \mathrm{~h}$, and close monitoring of the reaction by TLC, consistently gave the desired thioamide products in $67-96 \%$ isolated yields, after purification by column chromatography (Schemes 1 and 2). No evidence of any remaining starting dipeptides was observed by TLC and the chromatographic purification was straightforward.

The dipeptides and their thioamide analogues were fully characterised using a range of spectroscopic techniques, where ${ }^{1} \mathrm{H}$ and ${ }^{13} \mathrm{C}$ NMR spectroscopy showed the diagnostic downfield movement in the chemical shifts for both the carbon atom of the amide carbonyl 
group and the amide $\mathrm{N}-\mathrm{H}$ proton, when the amides were converted to their thioamide derivatives $^{12}$ (Table 1).

\begin{tabular}{|c|c|c|c|}
\hline Structure & Analogue & $\begin{array}{c}\text { Amide/Thioamide } \\
\mathrm{C}=\mathrm{O} / \mathrm{C}=\mathrm{S} \\
(\mathrm{ppm})\end{array}$ & $\underset{\text { (ppm) }}{\mathbf{N H}}$ \\
\hline FmocHN & $\begin{array}{c}\mathrm{R}=\mathrm{CH}_{2-} \\
\mathrm{Ph}(\mathbf{1}) \\
\mathrm{R}=\mathrm{CH}_{3} \\
(\mathbf{2}) \\
\mathrm{R}=\mathrm{H} \\
(\mathbf{3})\end{array}$ & $\begin{array}{l}171.5 \\
171.2\end{array}$ & $\begin{array}{l}6.33 \\
6.52\end{array}$ \\
\hline $\mathrm{FmocHN}^{\prime}$ & $\begin{array}{c}\mathrm{R}=\mathrm{CH}_{2-} \\
\mathrm{Ph}(\mathbf{4}) \\
\mathrm{R}=\mathrm{CH}_{3} \\
(\mathbf{5}) \\
\mathrm{R}=\mathrm{H} \\
(\mathbf{6})\end{array}$ & $\begin{array}{l}204.1 \\
203.9 \\
204.1\end{array}$ & $\begin{array}{l}8.21 \\
8.59 \\
8.14\end{array}$ \\
\hline FmocHN & $\begin{array}{c}\mathrm{R}^{\prime}= \\
\mathrm{CH}_{2}-\mathrm{Ph} \\
\mathbf{( 7 )} \\
\mathrm{R}^{\prime}=\mathrm{CH}_{3} \\
(\mathbf{8}) \\
\mathrm{R}^{\prime}=\mathrm{H} \\
(\mathbf{9})\end{array}$ & $\begin{array}{l}171.4 \\
172.1 \\
172.1\end{array}$ & $\begin{array}{l}6.13 \\
6.71 \\
6.63\end{array}$ \\
\hline $\mathrm{FmocHN}^{-}$ & $\begin{array}{c}\mathrm{R}^{\prime}= \\
\mathrm{CH}_{2}-\mathrm{Ph} \\
(\mathbf{1 0}) \\
\mathrm{R}^{\prime}=\mathrm{CH}_{3} \\
(\mathbf{1 1}) \\
\mathrm{R}^{\prime}=\mathrm{H} \\
(\mathbf{1 2})\end{array}$ & $\begin{array}{l}202.3 \\
204.9\end{array}$ & 8.24 \\
\hline
\end{tabular}

Table 1. Key ${ }^{1} \mathrm{H}$ and ${ }^{13} \mathrm{C}$ NMR chemical shifts for the characterisation of dipeptides and thioamide derivatives 
With the orthogonally protected thioamide dipeptides in hand it was then required that the $t$ butyl ester be efficiently removed, so that the Fmoc-protected thioamide dipeptides with a free carboxylic acid could be used for SPPS. This was readily achieved ( 90\% yield) by treating the orthogonally protected thioamide dipeptides with 50\% TFA in DCM in the presence of triphenylsilane as a scavenger (Scheme 3).

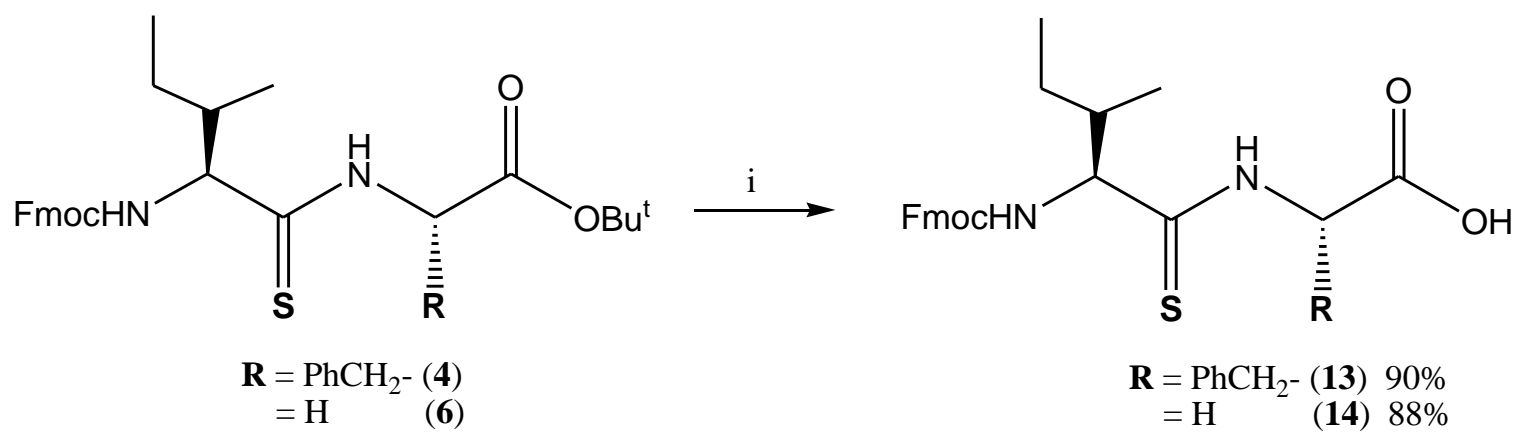

Scheme 3. Representative examples of deprotection of $t$-butyl ester group to give thioamide dipeptides 13 and 14, ready for SPPS. Reagents and conditions; i) 50\% TFA in DCM, Ph3SiH, rt, $2 \mathrm{~h}$

In conclusion the use of $\mathrm{P}_{4} \mathrm{~S}_{10}$ and $\mathrm{HMDO}$ to cleanly and selectively thionate the peptide bond of orthogonally protected dipeptides was achieved to consistently give the desired compounds in good yields. This was in contrast to the use of Lawesson's reagent or Berzelius' reagent, where incomplete reaction and/or decomposition, as well as difficulties with purification, was observed in every case. Subsequent $C$-terminus deprotection gave the thioamide dipeptide fragments (13 and 14) suitable for incorporation into peptide sequences by SPPS. The thioamide dipeptides are now being used for this purpose and the results of these studies will be reported in due course.

\section{Supplementary data}

Synthetic methods and characterisation data for compounds 1-14.

\section{Acknowledgements}

We are grateful to Science Foundation Ireland for funding for KM (Grant number 11/RFP.1/CHS/3306).

\section{References and Notes}


1. World Health Organisation (2014), Antimicrobial Resistance: Global report on surveillance. http://www.who.int/drugresistance/documents/surveillancereport/en/, accessed on June $24^{\text {th }} 2016$.

2. Review on Antimicrobial Resistance (2016), Tackling Drug-Resistant Infections Globally: Final Report and Recommendations, http://amr-review.org/Publications, accessed on October $4^{\text {th }} 2016$.

3. Transparency Market Research (2016), Global Peptide Therapeutics Market, http://www.transparencymarketresearch.com/pressrelease/global-peptidetherapeutics-market.htm, press release accessed on October $4^{\text {th }} 2016$.

4. (a) Sosio, M.; Donadio, S. in Antibiotics: Current Trends and Future Innovations, Chapter 17, ed. Sánchez, S.; Demain, A. L. Caister Academic Press 2015. ISBN: 978-1-908230-54-6; (b) Ongey, E. L.; Neubauer, P. Microb. Cell Fact. 2016, DOI 10.1186/s12934-016-0502-y; (c) Bahar, A. A.; Ren, D. Pharmaceuticals 2013, 6, 1543-1575.

5. (a) Just-Baringo, X.; Albericio, F.; Álvarez, M. Mar. Drugs 2014, 12, 317-351; (b) Bagley, M. C.; Dale, J. W.; Merritt, E. A.; Xiong, X. Chem. Rev. 2005, 105, 685714.

6. (a) Boström, J.; Olsson, R. I.; Tholander, J.; Greasley, P. J.; Ryberg, E.; Nordberg, H.; Hjorth, S.; Cheng, L. Bioorg. Med. Chem. Lett. 2010, 20, 479-482; (b) Zacharie, B.; Lagraoui, M.; Dimarco, M.; Penney, C. L.; Gagnon, L. J. Med. Chem. 1999, 42, 2046-2052.

7. Koketsu, M.; Ishihara, H. Curr. Org. Synth. 2007, 4, 15-29.

8. Ozturk, T.; Ertas, E.; Merl, O. Chem. Rev. 2007, 107, 5210-5278.

9. Ozturk, T.; Ertas, E.; Merl, O. Chem. Rev. 2010, 110, 3419-3478.

10. Curphey, T. J. J. Org. Chem. 2002, 67, 6461-6473.

11. Bergman, J.; Pettersson B.; Hasimbegovic, V.; Svensson, P. H. J. Org. Chem. 2011, $76,1546-1553$. 
12. Bach, A.; Eildal, J. N.; Stuhr-Hansen, N.; Deeskamp, R.; Gottschalk, M.; Pedersen, S. W.; Kristensen, A. S.; Strømgaard, K. J. Med. Chem. 2011, 54, 1333-1346.

13. Shibahara, F.; Sugiura, R.; Murai, T. Org. Lett. 2009, 11, 3064-3067.

14. Poupaert, J. H.; Carato, P.; McCurdy, C. R. Lett. Org. Chem. 2005, 2, 330-333. 